\title{
Rules and Regulations for the Investment Account
}




\title{
INTERNATIONAL MONETARY FUND
}

\section{IMF POLICY PAPER}

\section{RULES AND REGULATIONS FOR THE INVESTMENT ACCOUNT}

IMF staff regularly produces papers proposing new IMF policies, exploring options for reform, or reviewing existing IMF policies and operations. The following document has been released:

- Rules and Regulations for the Investment Account, which were adopted on January 23, 2013 and amended thereafter, were further amended on May 13, 2019 by the Executive Board of the IMF.

The IMF's transparency policy allows for the deletion of market-sensitive information and premature disclosure of the authorities' policy intentions in published staff reports and other documents.

\author{
Electronic copies of IMF Policy Papers \\ are available to the public from \\ http://www.imf.org/external/pp/ppindex.aspx \\ International Monetary Fund \\ Washington, D.C.
}

(C) 2019 International Monetary Fund 


\section{Rules and Regulations for the Investment Account}

\section{GENERAL PROVISIONS}

\section{OBJECTIVE OF THE INVESTMENT ACCOUNT}

1. The objective of the Investment Account (IA) is to provide a vehicle for the investment of a part of the Fund's assets so as to generate income that may be used to meet the expenses of conducting the business of the Fund. Achieving this objective would help diversify the sources and increase the level of the Fund's income, thereby strengthening its finances over time.

\section{SOURCES OF INVESTMENT ACCOUNT ASSETS}

2. The IA may be funded with: (a) currencies transferred from the General Resources Account (GRA) in accordance with Article XII, Section 6(f)(ii) of the Articles; (b) the placement of profits from the sale of pre-Second Amendment gold in accordance with Article V, Section 12(g) of the Articles, in amounts up to the total amount of the Fund's general and special reserves at the time of any decision authorizing such transfers; (c) the transfer of profits from the sale of post-Second Amendment gold in accordance with Article $V$, Section 12(k) of the Articles; and $(d)$ income from the IA investment that is not transferred to the General Resources Account to meet the expenses of the Fund (Article XII, Section 6(f)(iv)).

\section{INVESTMENT ACCOUNT SUBACCOUNTS}

3. The IA shall have a Fixed-Income Subaccount and an Endowment Subaccount, each of which has its own investment objective and shall be managed in accordance with Sections I and II, and I and III, respectively, of these Rules and Regulations (Rules).

4. Transfers of assets between subaccounts may be made with the approval of the Executive Board.

\section{RESPONSIBILITIES OF THE MANAGING DIRECTOR}

5. The Managing Director is responsible for implementing the investment policies set out in these Rules.

6. In carrying out the Managing Director's responsibilities, the Managing Director shall (a) establish effective decision-making and oversight arrangements; (b) take the necessary measures, including the adoption of policies and procedures, that seek to avoid actual or perceived conflicts of interest; and (c) establish specific risk control measures and put in place mechanisms to monitor their observance by asset managers. 
7. The Managing Director shall consult with the Executive Board regarding (a) the key conflict of interest policies and arrangements in the Managing Director's responsibility referred to in paragraph 6; and (b) the key aspects of the investment strategy for the actively managed portion of the Endowment Subaccount referred to in paragraph 30 of these Rules.

8. The Managing Director shall provide annual reports to the Executive Board on the investment activities of the IA. Ad hoc reports shall be prepared as warranted by market or other developments.

\section{EXTERNAL ASSET MANAGERS}

9. All assets of the IA shall be managed by external asset managers, except that the Managing Director is authorized to manage: (a) investments in obligations of the Bank for International Settlements (BIS) and central bank deposits; and (b) other assets on an interim basis following the termination of an external asset manager and pending the transfer of the assets to another external asset manager.

10. The Managing Director shall only select external asset managers of the highest professional standards and shall take into account their proven skills and track record suitable to achieve the investment objectives and to carry out the investment strategies set out under these Rules.

\section{CUSTODY ARRANGEMENTS}

11. The Managing Director shall establish adequate measures for the safekeeping and custody of the assets of the IA.

\section{USE OF INVESTMENT ACCOUNT INCOME}

12. The income from investment shall be invested, retained in the IA or used to meet the expenses of conducting the business of the Fund. The Fund shall decide on the use of the IA's income for each financial year, including whether any portion of such income will be transferred to the GRA for use in meeting the expenses of conducting the business of the Fund.

\section{TERMINATION OR REDUCTION OF THE INVESTMENT ACCOUNT}

13. The IA shall be terminated in the event of a liquidation of the Fund and may be terminated, or the amount of the investment may be reduced, prior to the liquidation of the Fund, by a 70 percent majority of the total voting power. The procedures specified in Article XII, Sections 6(f)(vii), (viii) and (ix) of the Articles will apply in the event of the termination of the IA or a reduction in its assets. The Fund's decision to reduce investments in the IA shall specify the subaccount from which assets shall be used to fund a reduction in investments. 


\section{AUDIT}

14. The assets of the IA shall be audited by the Fund's external auditors and included in the Fund's annual financial statements.

\section{REVIEW OF THE RULES AND CONFLICT OF INTEREST POLICIES}

15. The Executive Board is expected to review these Rules and the Fund's relevant conflict of interest policies every five years.

\section{FIXED-INCOME SUBACCOUNT INVESTMENT OBJECTIVE}

16. With a view of generating income while protecting the Fund's balance sheet, the investment objective of the Fixed-Income Subaccount is to achieve investment returns in SDR terms that exceed the 3-month SDR interest rate over time while minimizing the frequency and extent of negative returns and underperformance over an investment horizon of three to four years.

\section{ASSET ALLOCATION AND TRANCHES}

17. (a) The Fixed-Income Subaccount shall consist of two tranches, a shorter-duration Tranche 1 and a longer-duration Tranche 2.

(b) Tranche 1 assets shall be managed actively against a 0-3 year government bond benchmark index, weighted to reflect the currency composition of the SDR basket. The Managing Director shall establish in the investment management agreements the permitted degree of active management against the benchmark. Eligible asset classes for Tranche 1 are Group 1 and Group 2 asset classes as defined in paragraph 18 below.

(c) Tranche 2 assets shall be managed according to a buy-and-hold investment approach against a $0-5$ year government bond benchmark index, weighted to reflect the currency composition of the SDR basket, subject to subparagraph (e) below. Eligible asset classes for Tranche 2 are Group 1 assets as defined in paragraph 18 below.

(d) Asset transfers between Tranche 1 and Tranche 2, and the allocation to Tranche 1 and Tranche 2 of future inflows to, outflows from, the Fixed-Income Subaccount shall be determined by the Managing Director.

(e) The assets in Tranche 2 shall be phased over a five-year period, with the specific modalities of the phasing to be determined by the Managing Director. The phasing may be suspended or extended up to one year in case of exceptional market conditions.

\section{ELIGIBLE INVESTMENTS}


18. (a) "Group 1 asset classes" shall be limited to:

i. debt obligations issued by national governments of members or their central banks;

ii. debt obligations issued by national agencies of the members whose currencies are in the SDR basket;

iii. debt obligations issued by international financial institutions; and

iv. obligations issued by the BIS, including without limitation deposits with the BIS and MTIs;

all of which shall be denominated in SDR or the currencies included in the SDR basket.

(b) "Group 2 asset classes" shall be limited to:

i. debt obligations issued by national governments of members or their central banks denominated in non-SDR currencies selected by the Managing Director or, upon the authorization by the Managing Director, by external managers, provided that any currency selection shall be based on ex-ante criteria determined by the Managing Director;

ii. debt obligations denominated in SDR or the currencies included in the SDR basket, comprising: (A) securities issued by subnational governments;

iii. (B) mortgage-backed and other asset-backed securities; (C) covered bonds; and

(D) short-dated unsecured corporate bonds; and

iv. cash-equivalent investments with maturities of one year or less, that are denominated in SDR or the currencies included in the SDR basket.

(c) The Managing Director shall establish the parameters for determining the eligible investments within the categories of the asset classes specified in this paragraph.

19. Up to the maximum 35 percent of the total value of the Fixed-Income Subaccount assets may be invested in Group 2 asset classes, and the breach of this limit shall require prompt action to bring the Fixed-Income Subaccount back within the established limit.

20. In addition to investing in Groups 1 and 2 asset classes, the Fixed-Income Subaccount may temporarily hold uninvested cash balances, including in short-term instruments of the custodian(s).

\section{MINIMUM CREDIT RATING}

21. Except for obligations of the BIS, central bank deposits and uninvested cash balances, all assets in which the Fixed-Income Subaccount invests must have a credit rating equivalent to at least A (based on Standard \& Poor's long-term rating scale) by a major credit rating agency at the time of acquisition. The Managing Director may establish higher credit ratings for eligible individual asset classes. 
22. In cases where an asset is not directly rated, the Managing Director may determine whether a credit rating may be inferred for such asset in a manner that is consistent with market practice.

\section{DIVESTMENT}

23. Any eligible investment that ceases to meet the rating threshold under paragraph 21 or otherwise becomes ineligible after acquisition shall be divested within three months, except that corporate bonds which fail to meet the rating threshold under paragraph 21 after acquisition may be divested or continue to be retained in accordance with modalities established by the Managing Director.

\section{LIMITS ON INVESTMENT ACTIVITIES}

24. The Managing Director shall establish adequate safeguards against short selling and financial leverage.

25. The exchange rate risk for eligible investments denominated in non-SDR currencies shall be hedged back into SDR basket currencies with the objective to preserve the Fixed-Income Subaccount's SDR basket composition. Currency hedging may be used for SDR basket replication or for achieving overall currency exposure in line with SDR basket.

26. Derivatives may be used for managing interest rate risk, currency hedging, or reducing costs in the context of portfolio balancing, benchmark replication, and market access.

\section{ENDOWMENT SUBACCOUNT}

\section{INVESTMENT OBJECTIVE}

27. The investment objective of the Endowment Subaccount is to achieve a long-term real return target of 3 percent in U.S. dollar terms. This is consistent with the objective of generating investment returns to contribute to the Fund's income, while preserving the long-term real value of these resources. The subaccount's real return shall be calculated by using the deflator that is used for purposes of the Fund's administrative budget, the Global External Deflator (GED), provided that the U.S. consumer price index (U.S. CPI) component of the GED shall be adjusted to use the actual U.S. CPI instead of the projected U.S. CPI. 


\section{STRATEGIC ASSET ALLOCATION AND INVESTMENT STRATEGY}

28. No less than 90 percent of the Endowment Subaccount assets shall be managed passively (the "passively managed portion"), with up to 10 percent of the Endowment Subaccount assets managed actively in accordance with paragraph 30 below (the "actively managed portion").

29. The passively managed portion shall be invested pursuant to the following strategic asset allocation (SAA) benchmark: 15 percent in developed market sovereign bonds; 20 percent in U.S. Treasury Inflation-Protected Securities (US TIPs); 15 percent in developed market corporate bonds; 5 percent in emerging market bonds; 25 percent in developed market equities; 10 percent in emerging market equities; 5 percent in infrastructure debt; and 5 percent in real estate investment trusts (REITs). The Managing Director shall establish the parameters for determining eligible investments for the asset classes of the SAA and the modalities for appropriate passive investment approaches.

30. The actively managed portion may be invested only in the same asset classes as the SAA benchmark for the passively managed portion, with 60 percent in fixed-income instruments and 40 percent in equities (including REITs) and a permitted maximum deviation of \pm 15 percentage points for each category, but no specific allocation requirements for each asset class within these two categories. The Managing Director, in consultation with the Executive Board, shall determine the investment strategy and investment arrangements for the actively managed portion of the Endowment Subaccount, including the selection criteria and risk parameters for external managers, benchmark indices, the scope and instruments for currency hedging, the phasing of the actively managed portion of the Endowment Subaccount, policy bands and rebalancing procedures, and additional key measures to avoid actual or perceived conflicts of interest.

31. The asset allocation benchmarks for both the passively and actively managed portions shall not apply to uninvested cash balances, including such balances being held temporarily in short-term instruments of the custodian(s).

\section{REBALANCING OF THE PASSIVELY MANAGED PORTION}

32. Based on modalities established by the Managing Director, the passively managed portion shall be rebalanced at least annually to minimize deviation from the SAA benchmark specified in paragraph 29 above, or more frequently in the event of significant deviation.

\section{MINIMUM CREDIT RATINGS}

33. With the exception of obligations of the BIS, fixed-income assets in which the Endowment Subaccount invests are subject to the following minimum credit rating requirements at the time of acquisition by a major credit rating agency (based on Standard \& Poor's long-term rating scale): 
(a) BBB- for corporate bonds and infrastructure debt, provided that the Managing Director may establish modalities for allowing limited investment in infrastructure debt that is rated below BBB- at time of acquisition; and (b) BBB + for remaining assets.

34. In cases where an asset is not directly rated, the Managing Director may determine whether a credit rating may be inferred for such asset in a manner that is consistent with market practice.

\section{DIVESTMENT}

35. Any eligible investment that ceases to meet the rating threshold under paragraph 33 or otherwise becomes ineligible after acquisition shall be divested within three months, except that corporate bonds and infrastructure debt which fail to meet the rating threshold under paragraph 33 after acquisition may be divested or continue to be retained in accordance with modalities established by the Managing Director.

\section{LIMITS ON INVESTMENT ACTIVITIES}

36. The Managing Director shall establish adequate safeguards against short selling and financial leverage.

37. The exchange rate risk for fixed-income securities denominated in developed market currencies vis-à-vis the U.S. dollar shall be hedged for the passively managed portion of the Endowment Subaccount. Currency hedging is not permitted for other assets of the passively managed portion of the Endowment Subaccount.

38. For the passively managed portion, derivatives may be used for managing interest rate risk, currency hedging operations required under paragraph 37, or reducing costs in the context of portfolio balancing, benchmark replication and market access.

39. For the actively managed portion, currency hedging and derivatives may be used as determined by the Managing Director subject to adequate risk control parameters. 